\title{
Characterization of Humat Compounds Spectroscopy Under Different Soil Management Systems on Mount Bromo West Slope
}

\author{
Purnomo Edi Sasongko ${ }^{1, a}$, Wanti Mindari ${ }^{2, a}$ \\ a Department of Agrotechnology \\ Universitas Pembangunan Nasional "Veteran" Jawa Timur \\ Surabaya, Indonesia \\ ${ }^{1}$ purnomoedis@upnjatim.ac.id, ${ }^{2}$ wanti_m@upnjatim.ac.id
}

\author{
Purwanto $^{\mathrm{b}}$, Widyatmani Sih Dewi ${ }^{\mathrm{b}}$, Ramdan Hidayat ${ }^{\mathrm{b}}$ \\ ${ }^{\mathrm{b}}$ Graduate School Program \\ Universitas Sebelas Maret \\ Surakarta, Indonesia
}

\begin{abstract}
Soil organic matter (OM) is very important in its function, but information about the chemical composition, chemical structure and the changes caused by anthropogenic factors in the processing system is still in the research. The research objective is to examine the characteristics of organic materials and their derivatives, and their functions in various land use changes. Soil samples were taken at a depth of $0-20 \mathrm{~cm}$ in the Bromo mountainous lands under changes in land use of: coffee gardens (CT); apple orchard (AT); vegetable garden (VT) and secondary forest (SF). Soil samples were analyzed for C-org content, humic acid, $\mathrm{pH}, \mathrm{CEC}$, total of $\mathrm{P}$, aggregate stability, and redox potential. The characteristics of humic acid were analyzed using Fourier Transform Infrared (FTIR), UV-Vis fluorescence spectroscopy and elemental analysis (CHNS). The FTIR spectrum of HAs is similar for all land uses. The results showed that humic characters varied between all samples tested. There is a positive correlation between changes in intensive land use to secondary forests with soil physical chemical characteristics, Corganic content and humic character.
\end{abstract}

Keywords-characteristics; FTIR; land use changes; C-org; physical chemical

\section{INTRODUCTION}

In tropical soils, due to conventional tillage it causes high levels of organic matter $(\mathrm{OM})$ turnover and significant loss of soil organic carbon because intense mineralization generally causes soil degradation faster than climate influences [1]. Tiessen [2] Obtained data on the loss of $30 \%$ of organic carbon in Oxisol in the northeastern region of Brazil after conventional soil treatment for 6 years. According to Silva et al. [3], monoculture soybeans, OM loss were $76 \%$ and $41 \%$ of initial OM content after 5 years in Yellow Red Latosols with $15-30 \%$ and $>30 \%$ clay content respectively, and $80 \%$ for soil with sandy quartz content. Cultivated land that is increasingly degraded is the basis for the use of conventional farming methods in Brazil, the application of no-till systems has grown exponentially over the past 5 years [4]. It is estimated that more than 14 million HA is not managed in Brazil at present, around $25 \%$ of the total area is for wheat cultivation.
The study which carried out with sandy clay Andosols from the western slopes of Mount Bromo is showing, low residues, high residues, and no-to-increase $\mathrm{C}$ and total $\mathrm{N}$ content [5]. Further improvement in structural stability [6] [7], cation exchange capacity [8] [9], and microbial activity [10] [11] are observed. Spectroscopic techniques such as Fourier Transform Infrared (FTIR) and fluorescence are used to identify functional groups and molecular structures in order to provide a better understanding of OM decomposition pathways and qualitative changes caused by management practices [12] [13]. This approach is carried out to identify possible structural changes caused by processes in soil humic acid (HAs) from Inceptisols with different tillage models using spectroscopic techniques.

The study which carried out with sandy clay Andosols from the western slopes of Mount Bromo is showing, low residues, high residues, and no-to-increase $\mathrm{C}$ and total $\mathrm{N}$ content [5]. Further improvement in structural stability [6] [7], cation exchange capacity [8] [9], and microbial activity [10] [11] are observed. The use of spectroscopic techniques such as Fourier Transform Infrared (FTIR) and fluorescence allows the identification of functional groups and molecular structures to provide a better understanding of $\mathrm{OM}$ decomposition pathways and qualitative changes caused by management practices [12] [13]. This approach is intended to identify possible structural changes caused by management in soil humic acid (HAs) from Inceptisols under different tillage practices using spectroscopic techniques.

\section{METHOD}

The research area is located in the district of Tutur $\left(112^{0} 48^{\prime} 00^{\prime \prime}-112^{0} 52^{\prime} 30^{\prime \prime}\right.$ E. $7^{0} 48^{\prime} 00^{\prime \prime}$ - 7057'00" S), Pasuruan Regency, East Java Province, about $850 \mathrm{~km}$ east of Jakarta (Figure 1). It is also located on the west side of Bromo Tengger Semeru National Park, with undisturbed secondary forests and forests of varying degrees of degradation and recovery. This area is generally characterized by hilly topography, with bumpy slopes and some flat areas. Height ranges from 500-1600 $\mathrm{m}$ above sea level for agricultural land and around 1300-1600 $\mathrm{m}$ above sea level for forest areas. The 
annual rainfall average in this area is $2295 \mathrm{~mm}$ while the daily average temperature of minimum and maximum respectively is $13.7{ }^{\circ} \mathrm{C}$ dan $25.9{ }^{\circ} \mathrm{C}$ [14]. The soil in this area is dominated by Inceptisols (Tutur Series0 [15] or Andosol district and Cambisol district [16]. Overall, low soil nutrient content and high soil clay dispersion indicate low fertility that is inherent and has a high erodibility. Land in the remaining secondary forests including relatively newly re-inhabited areas in a restricted buffer zone, show significantly higher soil organic matter (SOM) contents and lower bulk density compared to fertile soil.

Soil samples were taken from six types of land use along the top side of the western part of Mount Bromo at a depth of $0-20 \mathrm{~cm}$. Soil samples were dried in the laboratory and sieved through $2 \mathrm{~mm}$ sieves for distribution analysis of clay particles and $\mathrm{pH}$, while they passed to $0.5 \mathrm{~mm}$ sieve for $\mathrm{C}$-org, $\mathrm{N}$-total, $\mathrm{P}$-available, and CEC analysis. The particle size distribution and water aggregate stability are determined by dropper method [17] and a single sieve [18]. Soil organic matter, total nitrogen, soil $\mathrm{pH}$, and cation exchange capacity, each of one are determined using the Walkley-Black, semi-micro Kjeldahl, potentiometry and $\mathrm{NH}_{4} \mathrm{OAc}$ method [4]. Humic acid content is analyzed gravi-metrically. The characteristics of humic acid were analyzed using Fourier transform infrared spectroscopy (FTIR) (Thermo Scientific, USA; Model: Nicolet ${ }^{\mathrm{TM}}$ iS10) and Scanning electron microscopy (SEM) (Model: $\mathrm{FEI}^{\mathrm{TM}}$ Inspect S50, USA) with EDX software.

The results of the analysis of the properties and characteristics of the soil were tabulated and interpreted against in land use changes. The correlation between observations were analyzed using Excel. The character of humic acid is compared to the character of native humic acid according to Stevenson [19]. The role of them could be evaluated from the analysis of aggregate stability, and cation exchange capacity, as well as soil $\mathrm{pH}$.

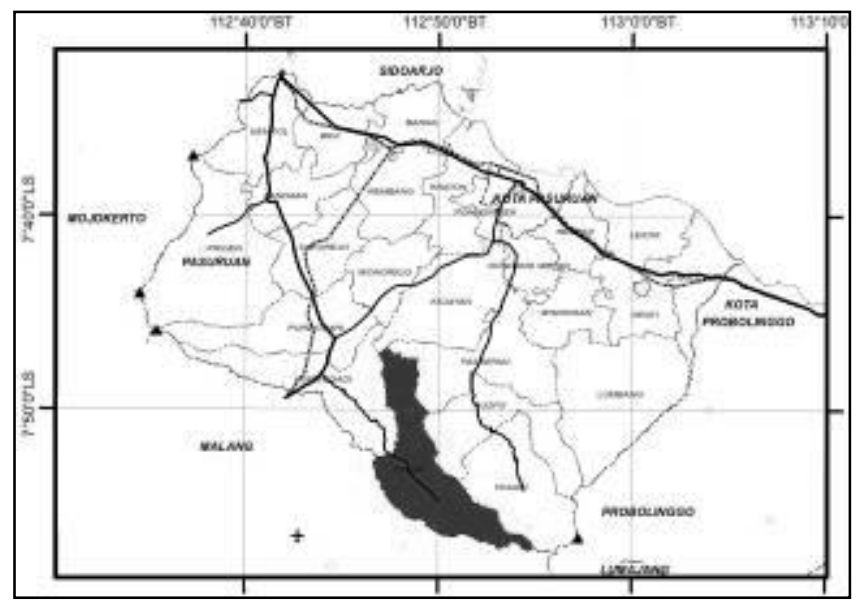

Fig. 1. Map of the research locations

\section{RESULT AND DISCUSSION}

The historical profile of land use reveals that permanent agriculture has been practiced in the area since the 1960s. When large portions of the original secondary forest are converted to agricultural land, the physico-chemical and organic matter characteristics of each soil sample change according to the data presented in Table 1.

TABLE I. PHYSICAL AND CHEMICAL CHARACTERISTICS OF TOP SOIL (0-15 CM)

\begin{tabular}{l|r|r|r|r|r|r}
\hline \multirow{2}{*}{ Soil samples analysis } & \multicolumn{7}{|c}{ Land Use Changes } \\
\cline { 2 - 7 } & \multicolumn{1}{c|}{ AF } & \multicolumn{1}{c}{ CT0 } & \multicolumn{1}{c}{ CT1 } & \multicolumn{1}{c}{ VT } & \multicolumn{1}{c}{ AT } & \multicolumn{1}{c}{ SF } \\
\hline C-org Total $(\%)$ & 0.87 & 2.00 & 2.56 & 4.00 & 2.09 & 1.36 \\
\hline N-org Total $(\%)$ & 0.37 & 0.45 & 0.51 & 0.51 & 0.49 & 0.47 \\
\hline $\mathrm{C} / \mathrm{N}$ & 2.40 & 4.40 & 5.00 & 7.80 & 4.30 & 2.90 \\
\hline Humic acid content $(\%)$ & 0,99 & 2,63 & 4,60 & 2,56 & 4,14 & 6,24 \\
\hline Soil P-Total $(\mathrm{ppm})$ & 12.38 & 19.81 & 32.18 & 42.91 & 22.28 & 27.23 \\
\hline $\mathrm{pH}\left(\mathrm{H}_{2} \mathrm{O}\right)$ & 6.33 & 5.73 & 5.41 & 4.75 & 4.54 & 4.42 \\
\hline $\mathrm{pH}(\mathrm{CaCl})$ & 5.07 & 4.35 & 4.76 & 4.65 & 4.77 & 4.91 \\
\hline $\mathrm{CEC}(\mathrm{cmol} / \mathrm{kg})$ & 8.50 & 12.24 & 12.60 & 14.62 & 13.60 & 13.26 \\
\hline Redox potential & +178 & +214 & +243 & +278 & +302 & +293 \\
\hline Clay $(\%)$ & 56 & 36 & 17 & 11 & 18 & 16 \\
\hline Aggregate stability $(\%)$ & 95.45 & 57.86 & 62.42 & 64.19 & 65.20 & 70.41 \\
\hline Note: AF & & & & &
\end{tabular}

Note: $\mathbf{A F}=$ mixed garden (agroforestry), CT0 $=$ Coffee garden without understory plant, CT1 = Coffee garden with understory plant, $\mathbf{V T}=$ Vegetable garden, $\mathbf{A T}=$ Apple garden, $\mathbf{S F}=$ Secondary forest of natural re-growth

The amount and character of organic matter is affected by land use changes. The level of oxidation indicated by soil redox also affects its availability. Land that receives input from organic materials from the return of harvest, manure and compost will increase the amount. Apple orchards are managed with high input of inorganic fertilizers and have rare canopies due to leaking, causing high oxidation rates, soil $\mathrm{pH}$ getting sour, and low $\mathrm{N}$ content presumed to be evaporated $\mathrm{NH}_{4}{ }^{+}$or washed out $\mathrm{NO}_{3}{ }^{-}$. Total $\mathrm{P}$ level of low soil may be bound by acidic or allophane minerals or absorbed by plants for fruit formation. The highest $\mathrm{P}$ content of vegetable garden soil may not be used by all plants so that it is left in the soil. Differences in coffee plantation management also affect soil physicochemical characteristics. If there is no plant under the coffee stand, then the amount of SOC and nutrients available is low and the humic carboxylic group is also reduced. Conversely, if under the coffee stand there is a plant, it will donate SOM and have the effects of reducing oxidation, increasing CEC, increasing plant nutrition, and soil aggregate stability.

\section{Characterization of Humic Acids}

By using Scanning Electron Microscopy with 5000 times magnification in Figure 2 shows the condition of land preparation and secondary forest (SF). The grain size of all HA soils is similar, with a difference only in micrometer scores, although the surface of the HA is clearly more developed. The structure of SF HA is smoother when compared to HA preparation soil; In addition, it can display parallel settings in each layer. 


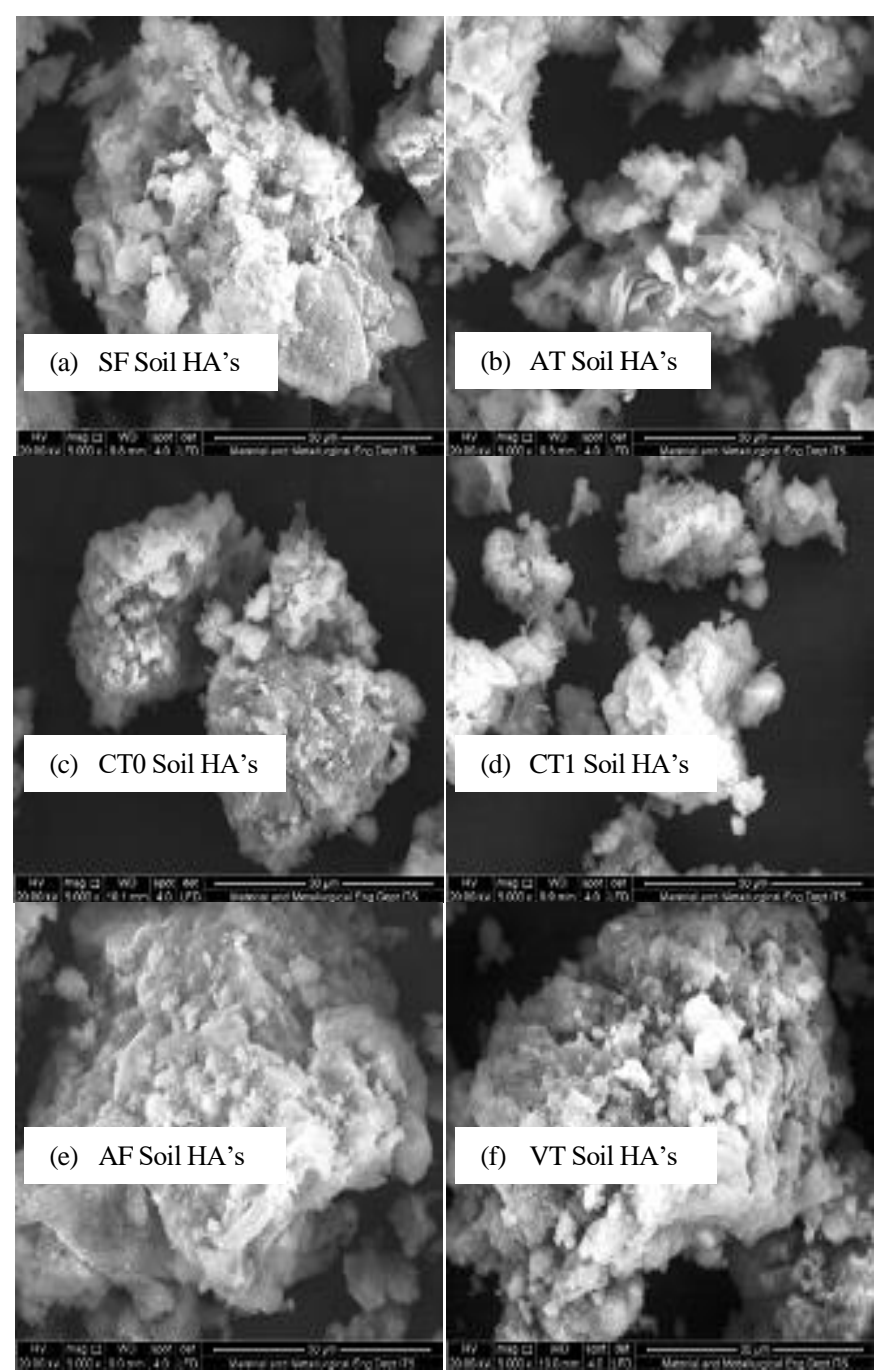

Fig 2. By the Scanning Electron Microscopy photos (magnification of x5000) shows the structure : (a) HA structure of secondary forest soil; (b-f) HA structure of tillage soils

Figure 3 shows the presence of the FT-IR Spectrum found in the graphite and graphene oxide samples studied. On all spectrums, oxidation is confirmed to have several bands associated with oxygen functionalization. A group of graphite absorbed by FT-IR is absorbed highest. The most intense peak (ie, the largest) occurs in the range $3320-3430 \mathrm{~cm}-1$

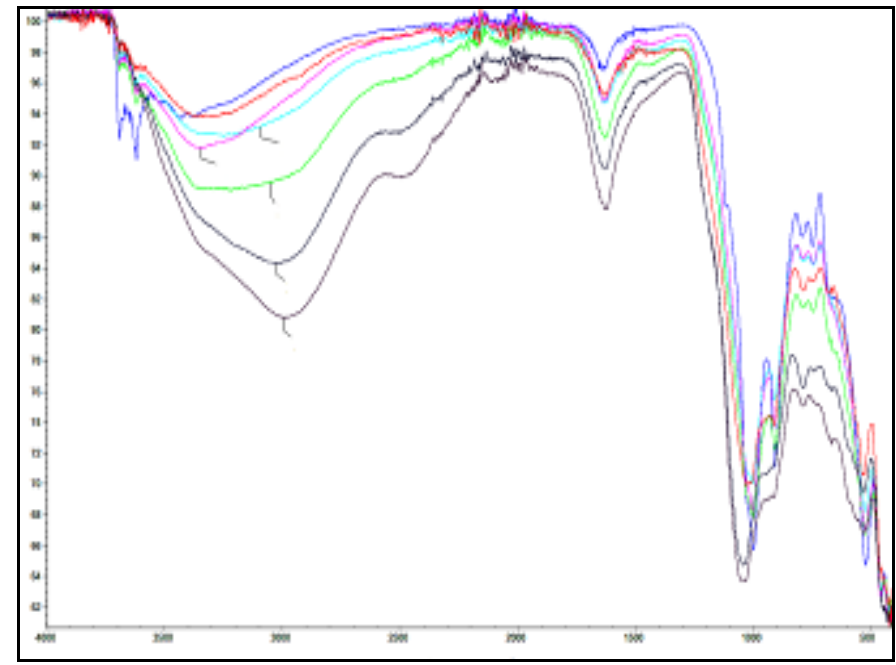

Fig 3. Characteristic FT -IR spectroscopy Humic Acid

\section{ACKNOWLEDGMENT}

This work was supported by the Directorate Research and Social Services Ministry of Research Technology and Higher Education Republic of Indonesia [Number: SP-DIPA 042.06.1.40156, 2017].

\section{REFERENCES}

[1] C. Shang and H. Tiessen, "Organic Matter Lability In A Tropical Oxisol: Evidence From Shifting Cultivation, Chemical Oxidation, Particle Size, Density, And Magnetic Fractionations," Soil Sci., vol. 162, no. 11, p. 795, Nov. 1997

[2] H. Tiessen, I. H. Salcedo, and E. V. S. B. Sampaio, "Nutrient and soil organic matter dynamics under shifting cultivation in semi-arid northeastern Brazil," Agric. Ecosyst. Environ., vol. 38, no. 3, pp. 139151, Feb. 1992

[3] J.E.Silva, J. Lemainski, D.V.S. Resck. "Perdas de materia organica e suas relacoes com a capacidade de troca cationica em solos da regiao de cerrados do oeste baiano," Rev. Bras. Cienc. Solo, vol 18, pp 541 - 547, Agosto 1994

[4] H.M. Saturnino, J.N. Landers (Eds). O Meio Ambiente e o Plantio Direto. EMBRAPA-SPI, Brasilia, pp. 25 - 26. Ch. 1, 1997

[5] C. Bayer, L. Martin-Neto, J. Mielniczuk, C.A. Ceretta, "Effect of no-till cropping system on soil organic matter in a sandy clay loam Acrisol from Southern Brazil monitored by electron spin resonance and nuclear magnetic resonance," Soil Tillage. Res., vol 53, pp 95 - 104. 2000.

[6] I.F. Silva, J. Mielniczuk, "Acao do sistema radicular de plantas na formacao e estabilizacao de agregados do sol," Rev. Bras. Cienc. Solo, vol 21, pp 113 - 117, 1997a.

[7] I.F. Silva, J. "Mielniczuk. Avaliacao do estado de agregacao do solo afectado pelo uso agrıcola” Rev. Bras. Cienc. Solo, vol 21, pp $313-319$, 1997b

[8] V.M. Testa. L.A.J. Teixeira, J. Mielniczuk, “Caracterı'sticas qu1'micas de um solo Podzólico Vermelho-escuro afetadas por sistemas de culturas," Rev. Bras. Cienc. Solo, vol 16, pp 107 - 114, 1992

[9] ML. Burle, J. Mielniczuk, S. Focchi, "Effect of cropping systems on soil chemical characteristics with emphasis on soil acidification," Plant Soil, vol 190, pp 309-316, 1997

[10] A.Cattelan, C. Vidor, "Sistemas de culturas e a populac $\square$ a o microbiana do solo" Rev. Bras. Cienc. Solo, vol 14, pp 125 - 132, 1990a

[11] A. Cattelan, C. Vidor, "Flutuac $\square$ o"es na biomassa, atividade e populac $\square$ a o microbiana do solo, em func $\square$ ão de variac $\square$ ões ambientais,” Rev. Bras. Cienc. Solo, vol 14, pp 133 - 142, 1990 b. 
[12] H.R. Schulten, M. Schnitzer, "A State of The Art Structural Concept for Humic Substances," Naturwissenschaften, vol 80, pp 29 - 30, 1993

[13] H.R. Schulten, Three-dimensional models for humic acids and soil organic matter. Naturwissenschaften, vol 82, pp 487 - 498, 1995

[14] CBS Pasuruan. Tutur District in Figure 2016. IDHS. Pasuruan Regency: Central Bureau of Statistics (CBS), 2016

[15] Soil Survey Staff. Keys to Soil Taxonomy, 12th ed. USDANatural Resources Conser- vation Service, Washington, DC, 2014

[16] D. Subardja, S. Ritung, M. Anda, Sukarman, E. Suryani, and R.E. Subandiono. National Soil Classification Technical Instructions Indonesian Center for Agricultural Land Resources Research and
Development, Bogor: Agricultural Research and Development Board, pp 22, 2014.

[17] Soil Survey Staff. Soil Survey Field and Laboratory Methods Manual. Soil Survey Investigations Report No. 51, Version 2.0. R. Burt and Soil Survey Staff (ed.), U.S: Department of Agriculture, Natural Resources Conservation Service, 2014.

[18] W.P. Miller, D.M. Miller, "A micropippete method for soil mechanical analysis," Communications in Soil Science and Plant Analysis, vol. 18 (1), 1987 